\title{
BMJ Open Out-of-hours antibiotic prescription after screening with $C$ reactive protein: a randomised controlled study
}

\author{
Ingrid Keilegavlen Rebnord, ${ }^{1,2}$ Hogne Sandvik, ${ }^{1}$ Anders Batman Mjelle, ${ }^{3}$ \\ Steinar Hunskaar ${ }^{1,2}$
}

To cite: Rebnord IK, Sandvik H, Batman Mjelle A, et al. Out-of-hours antibiotic prescription after screening with $C$ reactive protein: a randomised controlled study. BMJ Open 2016;6: e011231. doi:10.1136/ bmjopen-2016-011231

- Prepublication history for this paper is available online. To view these files please visit the journal online (http://dx.doi.org/10.1136/ bmjopen-2016-011231).

Received 21 January 2016 Revised 5 April 2016 Accepted 26 April 2016

\section{CrossMark}

For numbered affiliations see end of article.

\section{Correspondence to} Dr Ingrid Keilegavlen Rebnord;

ingrid.rebnord@uni.no

\section{ABSTRACT}

Objective: To evaluate the effect of preconsultation $C$ reactive protein (CRP) screening on antibiotic prescribing and referral to hospital in Norwegian primary care settings with low prevalence of serious infections. Design: Randomised controlled observational study at out-of-hours services in Norway.

Setting: Primary care.

Participants: 401 children (0-6 years) with fever and/or respiratory symptoms were recruited from 5 different outof-hours services (including 1 paediatric emergency clinic) in 2013-2015.

Intervention: Data were collected from questionnaires and clinical examination results. Every third child was randomised to a CRP test before the consultation; for the rest, the doctor ordered a CRP test if considered necessary.

Outcome measures: Main outcome variables were prescription of antibiotics and referral to hospital.

Results: In the group pretested with CRP, the antibiotic prescription rate was $26 \%$, compared with $22 \%$ in the control group. In the group pretested with CRP, $5 \%$ were admitted to hospital, compared with $9 \%$ in the control group. These differences were not statistically significant. The main predictors for ordering a CRP test were parents' assessment of seriousness of the illness and the child's temperature. Paediatricians ordered CRP tests less frequently than did other doctors ( $9 \%$ vs $56 \%, p<0.001$ ). Conclusions: Preconsultation screening with CRP of children presenting to out-of-hours services with fever and/or respiratory symptoms does not significantly affect the prescription of antibiotics or referral to hospital.

Trial registration number: NCT02496559; Results.

\section{INTRODUCTION}

Fever, respiratory symptoms and infections are common among children in primary care, especially at out-of-hours (OOH) services. ${ }^{1}$ Serious infections have low prevalence in primary care, and even more so after introduction of vaccines for Haemophilus influenzae type B and pneumococcal conjugate vaccines. ${ }^{2}{ }^{3}$ It is challenging for clinicians to distinguish serious and low-prevalent

\section{Strengths and limitations of this study}

- The study is a randomised controlled trial evaluating the effect on antibiotic prescription and hospital referral by screening children with fever and/or respiratory symptoms with a $C$ reactive protein (CRP) test before the consultation.

- Nearly complete data since we used dedicated nurses to collect clinical symptoms and findings on all children.

- The study was underpowered, that is, the differences were too small to reach statistical significance.

- Identified predictors of CRP testing are observational and not a result of the randomised trial.

diseases from common, self-limiting infections. A severity-of-illness scoring system does not exist for primary care.

In Norway, $85 \%$ of antibiotics are prescribed in primary care. ${ }^{4}$ Despite a decrease in serious infections, the use of antibiotics has been increasing until 2012, and is generally believed to be unnecessarily widespread. ${ }^{5}$ Although there has been an increase in methicillin-resistant Staphylococcus aureus (MRSA), the prevalence of antibiotic resistant bacteria is lower than in most other countries. ${ }^{6}$ In order to keep the antimicrobial resistance low, it is important to avoid unnecessary antibiotics and use narrow spectrum penicillin when possible. ${ }^{7}$

$\mathrm{C}$ reactive protein (CRP) is an inflammation marker, reflecting the severity of inflammation and tissue injury, which is used as a tool to differentiate between bacterial and viral infections. ${ }^{8}$ It has high popularity in Norwegian primary care as a point-of-care test, and in $\mathrm{OOH}$ services it is used in more than half of all children with respiratory symptoms. ${ }^{19}$ It thus seems that CRP testing is more like a routine, rather than a supplement to history taking and clinical examination. 
The CRP test's role in ruling out or ruling in serious infections, and the cut-off value for when to prescribe antibiotics, have been widely discussed. ${ }^{8}{ }^{10}$ The impact of CRP as a way of reducing the number of antibiotic prescriptions is at best unclear. ${ }^{11-16}$

The aim of the present study was to evaluate the effect of preconsultation screening with CRP on antibiotic prescribing and referral to hospital for children aged 0-6 years presenting at $\mathrm{OOH}$ services with fever and/or respiratory symptoms.

\section{METHOD}

We designed a randomised controlled observational study including children aged 0-6 years with fever or any respiratory symptoms. The data consist of clinical symptoms and signs collected by a nurse at the $\mathrm{OOH}$ services before the doctor's consultation, a questionnaire filled in by the parents before the consultation, and the medical record. Every third child was randomised to a CRP test before the consultation with a predefined mark in their study folder. The remaining 2/3 received usual care, allowing the doctor to order a CRP test on individual indication. Other tests also available were rapid strep test, urine dipstick test, haemoglobin and glucose.

\section{Inclusion and procedures}

The inclusion of participants took place during the winter seasons from January 2013 to May 2015 at four different $\mathrm{OOH}$ services near Bergen and at one paediatric emergency clinic at Haukeland University Hospital in Bergen. This emergency clinic is a walk-in, open access facility, and it is located at a hospital and staffed by paediatricians.

The nurses at the $\mathrm{OOH}$ services were trained in the study inclusion criteria and examination procedures. At the paediatric emergency clinic, two trained nurses were engaged specially for the project. The parents were approached by the nurse and invited to participate in the study and fill out a questionnaire prior to the consultation. The nurse did a clinical examination of all children and a CRP test of every child randomised to the test. The CRP result followed the patient to the consultation but not the study folder with the results from the questionnaire. The diagnosis and treatment were recorded from the medical record after the consultation. Numbers of potential patients not asked or approached were not recorded.

\section{Variables}

The two main outcome variables were antibiotic prescription and referral to hospital. Recorded variables from the medical history were age, gender, previous chronic disease, duration of present illness, fever during the past $24 \mathrm{~h}$, variation in fever, vomiting, earache, coughing, dyspnoea, throat symptoms, diarrhoea, reduced diuresis, cervical rigidity, skin rash and use of paracetamol or ibuprofen during the past $24 \mathrm{~h}$. The parents' assessment of the illness and its seriousness was also recorded. Variables from the nurse's examination were temperature, respiratory rate, oxygen saturation, degree of hydration, capillary refill time and general condition on a three-point scale (normal, ill and severely ill). Finally, we recorded whether the doctor was a paediatrician or working at the $\mathrm{OOH}$ services.

\section{Study sample calculation}

A power calculation was based on the following presumptions: we presumed that $35 \%$ of all children would receive antibiotic treatment based on data from earlier studies, ${ }^{1718}$ and that CRP would be requested in every second consultation. ${ }^{1}$ Furthermore, we presumed that the doctor requested a CRP for the most seriously ill children and that $50 \%$ of these children would receive antibiotics, compared with $20 \%$ for the healthier nontested group. The null hypothesis was that pretested CRP would not change the frequency of antibiotic treatment, that is, $35 \%$ of both groups would receive antibiotics. If a $40 \%$ change (effect size) in antibiotic treatment due to pretested CRP was defined as significant, using a two-sided test, power $80 \%$, $\alpha$ level $5 \%$, the sample sizes would have to be $130+259$. If effect size was reduced from $40 \%$ to $20 \%$, the sample sizes would have to be $525+1050$. As it turned out, recruiting participants was challenging, and an interim analysis was performed when 400 children were included. The difference in antibiotic prescriptions was much smaller than what we considered clinically significant, and we therefore decided to stop further recruitment of participants.

\section{Statistical analysis}

Proportions were compared by $\chi^{2}$ tests, means by Student's $t$ tests. A logistic regression analysis was performed to analyse predictors for ordering a CRP. Explanatory variables that were significant in bivariate analyses were included in the final model. The significance level was set at 5\% $(\mathrm{p}<0.05)$. Data were analysed using IBM SPSS (V.21).

\section{RESULTS}

A total of 401 children were included in the study, but four left the clinic before the doctor's consultation, leaving 397 for inclusion in our analyses (figure 1). A comparison of the two randomised groups is shown in table 1 . The mean age was 2.3 years, and 223 (55.6\%) were boys. The mean duration of illness was 6.5 days and the mean temperature at the consultation was $38.0^{\circ} \mathrm{C}$. No significant differences were found, except that the general condition was more often assessed as normal in the group randomised to a CRP test. A similar comparison of children attending $\mathrm{OOH}$ services and the hospital clinic showed that those at the hospital clinic had a significantly lower temperature, respiratory rate, higher oxygen saturation, reported less use of paracetamol, and were assessed to be in better general condition than those at the $\mathrm{OOH}$ services (table 1). 


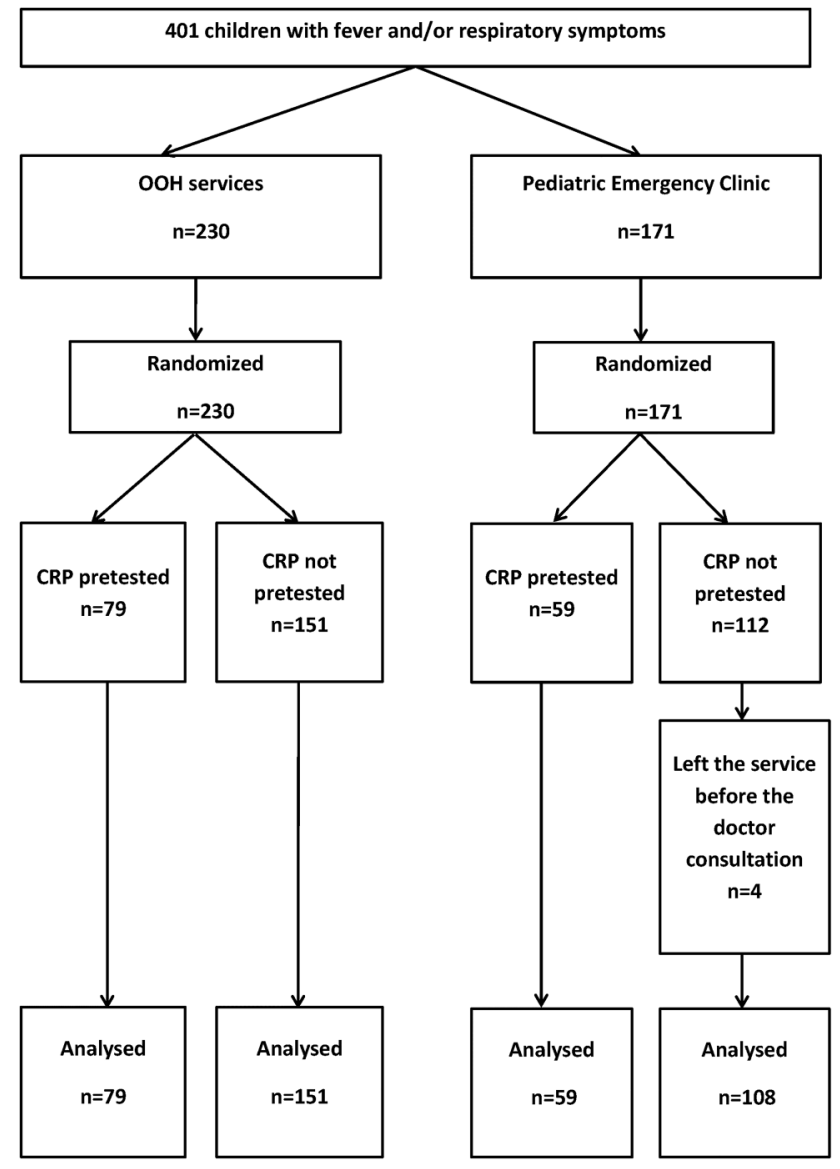

Figure 1 Flow chart over included and investigated patients in the study. CRP, C reactive protein; $\mathrm{OOH}$, out-of-hours.

A rapid strep test was taken in seven cases; all were negative, but three of the children got a prescription of antibiotics. A urine dipstick test was performed in three cases and two of the children were diagnosed with pyelonephritis.

In total, 93 (23\%) received a prescription for antibiotics and $31(8 \%)$ were admitted to hospital. In the group pretested with CRP, the antibiotic prescription rate was $26 \%$, compared with $22 \%$ in the control group. In the group pretested with CRP; $5 \%$ were admitted to hospital, compared with $9 \%$ in the control group (table 2).

The mean result of pretested CRP was significantly lower than when requested by the doctor (21 vs $34 \mathrm{mg} / \mathrm{L}$, $\mathrm{p}=0.006$ ). Paediatricians ordered CRP tests less frequently than did other doctors ( $9 \%$ vs $56 \%, \mathrm{p}<0.001)$.

In the logistic regression analyses, three variables remained significantly associated with ordering a CRP test. Use of CRP increased if the parents thought their child had a serious infection or if the child had a high temperature at the consultation. Use of CRP decreased if the doctor was a paediatrician (table 3).

Upper respiratory infection was the most frequently used diagnosis, followed by otitis media and tonsillitis (table 4). Antibiotic prescription rate was highest with tonsillitis (68\%) and otitis media/pneumonia (67\%). All patients with pneumonia not given antibiotics were referred to hospital (33\%). Pyelonephritis, dehydration, bronchiolitis and fever of unknown origin were the other most frequent reasons for referral to hospital.

\section{DISCUSSION \\ Summary}

In this randomised controlled study of preconsultation CRP testing of children with fever and/or respiratory symptoms, no significant effect was found on antibiotic prescription or hospital admittance. The study confirms that CRP tests are widely used in $\mathrm{OOH}$ services and the excessive use rather tends to increase the antibiotic prescription than to reduce it. High fever and concerned parents predict CRP testing. Paediatricians order CRP testing less frequently than do $\mathrm{OOH}$ doctors.

\section{Strengths and limitations}

Our data, according to protocol, are nearly complete due to the effort of the nurses. Collecting data from the medical record only would have been simpler and maybe increased the number of included children, but would probably have caused more missing data.

The inclusion was challenging since the nurses at the $\mathrm{OOH}$ services had to ask and inform the parents to participate, interview them and do some tests before the consultation, all this on top of their normal job. The study inclusion may have been given a lower priority on busy days. At the paediatric emergency clinic, we used a dedicated study nurse who was able to include all children for whom the parents consented.

The children who are seen by a paediatrician at the paediatric emergency clinic are unselected and not referred from primary care. At the $\mathrm{OOH}$ services, the doctor is a general practitioner (GP), a GP in training or locums. We have no detailed information about the experience of these $\mathrm{OOH}$ doctors but know that younger doctors are working more often $\mathrm{OOH}$ and use more CRP. ${ }^{9}{ }^{19}$ How the experience affects the prescription is not known. The paediatric emergency clinic had the function as an $\mathrm{OOH}$ service for children in Bergen city, but the children at the clinic seemed to be slightly healthier, maybe due to the walk-in, open access facility. At the other $\mathrm{OOH}$ services, the parents had to call first for advice and only got an appointment if the child was assessed to need a doctor consultation. ${ }^{20}$ This difference may have influenced the use of CRP tests and prescription of antibiotics. Doctors at the $\mathrm{OOH}$ services get an extra fee for each CRP test, while there is no such economic incentive at the paediatric emergency clinic. This may explain some of the difference in use of CRP tests.

The study was not blinded and knowledge about the purpose of the study may have influenced the doctor's prescription pattern. However, this influence would probably affect both groups equally.

One main limitation is the study sample, which was estimated from an expectation that preconsultation CRP 
Table 1 Comparison of background variables in the two randomised groups and the two different clinical settings

\begin{tabular}{|c|c|c|c|c|c|c|}
\hline \multirow[b]{2}{*}{ Variables } & \multicolumn{3}{|c|}{ Intervention group } & \multicolumn{3}{|c|}{ Clinical setting } \\
\hline & $\begin{array}{l}\text { Pretested } \\
\text { CRP } n=138\end{array}$ & $\begin{array}{l}\text { CRP not } \\
\text { pretested } \\
\mathrm{n}=259 \\
\end{array}$ & $\begin{array}{l}\text { p } \\
\text { Value }^{*}\end{array}$ & $\begin{array}{l}\text { OOH service } \\
\mathrm{n}=230\end{array}$ & $\begin{array}{l}\text { Paediatric } \\
\text { emergency } \\
\text { clinic } n=167\end{array}$ & $\begin{array}{l}p \\
\text { Valuet }\end{array}$ \\
\hline \multicolumn{7}{|l|}{ Age (year) } \\
\hline Mean (SD) & $2.13(1.7)$ & $2.44(1.9)$ & \multirow{2}{*}{0.104} & $2.38(1.7)$ & $2.29(1.9)$ & \multirow{2}{*}{0.638} \\
\hline Median (IQR) & $1.5(0.9-2.9)$ & $1.9(1.0-3.5)$ & & $1.9(1.0-3.5)$ & $1.5(0.9-3.0)$ & \\
\hline \multicolumn{7}{|l|}{ Duration illness (day) } \\
\hline Mean (SD) & $7.0(11.0)$ & $6.4(7.7)$ & \multirow[t]{2}{*}{0.434} & $6.0(7.7)$ & $7.2(9.9)$ & \multirow[t]{2}{*}{0.175} \\
\hline Median (IQR) & $4(3-7)$ & $4(2-7)$ & & $4(2-7)$ & $4(2-7)$ & \\
\hline \multicolumn{7}{|l|}{ Temperature $\left({ }^{\circ} \mathrm{C}\right)$} \\
\hline Mean (SD) & $38.0(0.9)$ & $37.9(1.0)$ & \multirow[t]{2}{*}{0.893} & $38.2(0.9)$ & $37.7(1.0)$ & \multirow[t]{2}{*}{$<0.001$} \\
\hline Median (IQR) & $\begin{array}{l}38.0 \\
(37.3-387)\end{array}$ & 37.9 & & $\begin{array}{l}38.1 \\
(37.5-39.0)\end{array}$ & $\begin{array}{l}37.4 \\
(36.9-38.4)\end{array}$ & \\
\hline \multicolumn{7}{|l|}{ Respiratory rate (breath/min) } \\
\hline Mean (SD) & $34.2(15.0)$ & $31.8(12.7)$ & \multirow[t]{2}{*}{0.118} & $34.0(13.4)$ & $30.9(13.6)$ & \multirow[t]{2}{*}{0.028} \\
\hline Median (IQR) & $30(20-42)$ & $28(20-40)$ & & $31(22-44)$ & $25(20-38)$ & \\
\hline Earache & 24.4 & 27.4 & 0.566 & 26.3 & 26.3 & 0.955 \\
\hline Cough & 86.1 & 84.0 & 0.665 & 85.1 & 84.8 & 0.987 \\
\hline Dyspnoea & 61.6 & 54.4 & 0.098 & 60.0 & 52.6 & 0.090 \\
\hline Diarrhoea & 19.1 & 18.6 & 0.657 & 18.9 & 18.7 & 0.963 \\
\hline $\begin{array}{l}\text { Taken paracetamol during the past } \\
24 \mathrm{~h}\end{array}$ & 65.9 & 66.5 & 0.783 & 73.4 & 57.3 & 0.001 \\
\hline Gender (male) & 53.6 & 56.7 & 0.502 & 57.8 & 52.6 & 0.370 \\
\hline \multicolumn{7}{|l|}{ General condition } \\
\hline Normal & 29.0 & 20.1 & \multirow[t]{3}{*}{0.052} & 18.3 & 29.2 & \multirow[t]{3}{*}{0.003} \\
\hline III & 68.8 & 76.8 & & 77.8 & 69.6 & \\
\hline Severely ill & 2.2 & 2.7 & & 3.5 & 1.2 & \\
\hline \multicolumn{7}{|l|}{ Pulse oximetry } \\
\hline$>95 \%$ & 53.6 & 58.7 & \multirow[t]{3}{*}{0.181} & 51.7 & 63.2 & \multirow[t]{3}{*}{0.002} \\
\hline $90-95 \%$ & 29.0 & 24.3 & & 30.0 & 20.5 & \\
\hline$<90 \%$ & 2.9 & 1.9 & & 3.5 & 0.6 & \\
\hline \multicolumn{7}{|l|}{ Earlier experienced CRP } \\
\hline Yes & 69.6 & 71.5 & \multirow[t]{3}{*}{0.800} & 76.9 & 63.2 & \multirow[t]{3}{*}{0.109} \\
\hline No & 2.2 & 1.5 & & 0.9 & 2.9 & \\
\hline Do not know & 18.8 & 20.2 & & 22.3 & 22.2 & \\
\hline \multicolumn{7}{|l|}{ Chronic disease } \\
\hline No disease & 75.4 & 74.1 & \multirow[t]{3}{*}{0.851} & 74.3 & 74.3 & \multirow[t]{4}{*}{0.948} \\
\hline Asthma & 18.1 & 20.8 & & 21.3 & 18.1 & \\
\hline Allergy/other & 6.5 & 5.0 & & 4.4 & 7.6 & \\
\hline Consultation with paediatrician & 42.8 & 42.6 & 0.840 & 0.0 & 100.0 & \\
\hline
\end{tabular}

screening would affect antibiotic prescription to a larger degree than what turned out to be true. If the differences found were to be statistically significant, the study sample would have to be several times larger. The number of referrals to hospital was small in this study and it is not possible to state from these data if screening with CRP affects it. Other laboratory tests (rapid strep test and urine dipstick) were used little.

Comparison with the existing literature

Children with fever and/or respiratory symptoms are frequent attenders at $\mathrm{OOH}$ services, but to compare the distribution of diagnoses is difficult because of the different diagnostic criteria and different precision level. In our material, there were a lot of symptom diagnoses, such as fever, cough, viral illness, upper respiratory infection, etc. This reflects how difficult it is to give a valid diagnosis in primary care. A high CRP result may indicate a more severe diagnosis, such as pneumonia, but rarely these diagnoses are validated in other ways (X-rays, sputum samples, etc).

In one study from general practice in the UK, including children aged $<5$ years with acute illness, ${ }^{21}$ lower respiratory infections were more common, and tonsillitis and ear infections less common than in our study. The antibiotic prescription rate was higher for all diagnoses, 
Table 2 Effect of preconsultation screening with CRP on the rate of antibiotic prescription and referral to hospital

\begin{tabular}{|c|c|c|c|c|c|}
\hline \multirow[b]{2}{*}{ Variables } & \multicolumn{2}{|c|}{$\begin{array}{l}\text { Intervention group CRP } \\
\text { pretested }\end{array}$} & \multicolumn{2}{|c|}{$\begin{array}{l}\text { No intervention CRP at } \\
\text { request }\end{array}$} & \multirow[b]{2}{*}{ p Value } \\
\hline & $\begin{array}{l}\text { Number of } \\
\text { patients }\end{array}$ & $\begin{array}{l}\text { Percentage } \\
(95 \% \mathrm{Cl})\end{array}$ & $\begin{array}{l}\text { Number of } \\
\text { patients }\end{array}$ & $\begin{array}{l}\text { Percentage } \\
(95 \% \mathrm{Cl})\end{array}$ & \\
\hline All children $n=397$ & $n=138$ & & $n=259$ & & \\
\hline Prescription of antibiotics & 36 & 26 (19 to 34$)$ & 57 & 22 (17 to 27$)$ & 0.361 \\
\hline Referral to hospital & 7 & 5 (1 to 9$)$ & 24 & $9(6$ to 13$)$ & 0.138 \\
\hline OOH services $n=230$ & $\mathrm{n}=79$ & & $n=151$ & & \\
\hline Prescription of antibiotics & 25 & 32 (21 to 42$)$ & 38 & 25 (18 to 32$)$ & 0.295 \\
\hline Referral to hospital & 4 & $5(0$ to 10$)$ & 12 & $8(4$ to 12$)$ & 0.414 \\
\hline Paediatric emergency clinic $n=167$ & $\mathrm{n}=59$ & & $n=108$ & & \\
\hline Prescription of antibiotics & 11 & 19 (8 to 29$)$ & 19 & 18 (10 to 25$)$ & 0.866 \\
\hline Referral to hospital & 3 & $5(-1)$ to 11$)$ & 12 & 11 (5 to 17$)$ & 0.193 \\
\hline
\end{tabular}

with a total prescription rate of $26 \%$ compared with $23 \%$ in our study. In two Dutch studies from OOH services, the prescription rate was $36 \%$ and $37 \%$ for febrile children; ${ }^{22} 23$ in a comparable study from paediatric outpatient settings in Sweden and Estonia, the prescription rate was $35 \%$ and $61 \% .^{24}$

In a comparable study from Norwegian general practice, the total antibiotic prescription rate was $26 \%$, but for otitis media it was only $42 \%$ compared with $67 \%$ in our study. ${ }^{25}$ For pneumonia and tonsillitis, the prescription rates were more similar, $71 \%$ and $79 \%$, compared with $67 \%$ for both in our study. It seems that the prescription rates in our study were rather low compared with other countries, but correspond well with earlier published Norwegian results. Norway still seems to be a low-prescription country.

The use of CRP at OOH services in Norway is high compared with other countries. In our study, CRP was ordered in $56 \%$ of consultations at the $\mathrm{OOH}$ services. In a Swedish study, CRP was ordered in $36 \%$ of all consultations. ${ }^{26}$ Another recently published Swedish study where both children and adults were included found CRP

Table 3 OR for ordering a CRP test in the group randomised to CRP at request, $n=259$

\begin{tabular}{|c|c|c|c|c|}
\hline Variable & CRP requested \% & OR & $\mathrm{Cl}(95 \%)$ & p Value \\
\hline \multicolumn{5}{|l|}{ Parents' assessment of sickness } \\
\hline No opinion $n=110$ & 44 & Ref. & & \\
\hline Viral infection $n=69$ & 25 & 0.51 & 0.16 to 1.59 & 0.248 \\
\hline Bacterial infection $n=79$ & 35 & 0.84 & 0.32 to 2.24 & 0.734 \\
\hline \multicolumn{5}{|l|}{ Parents' assessment of degree of seriousness } \\
\hline Think it is not serious but want a check $n=66$ & 17 & Ref. & & \\
\hline Not sure, maybe in need of treatment $n=97$ & 42 & 4.99 & 1.77 to 14.03 & 0.002 \\
\hline Think antibiotics are needed $n=89$ & 40 & 5.80 & 1.88 to 17.92 & 0.002 \\
\hline Think the child needs hospitalisation $n=6$ & 100 & NC & & \\
\hline Respiratory rate* & & 1.01 & 0.97 to 1.04 & 0.768 \\
\hline Temperature $\left({ }^{\circ} \mathrm{C}\right)^{*}$ & & 1.64 & 1.08 to2.48 & 0.019 \\
\hline \multicolumn{5}{|l|}{ Use of paracetamol during the past $24 \mathrm{~h}$} \\
\hline No $n=84$ & 24 & Ref. & & \\
\hline Yes $n=173$ & 42 & 1.43 & 0.59 to 3.42 & 0.428 \\
\hline \multicolumn{5}{|l|}{ Fever during the past $24 \mathrm{~h}$} \\
\hline No $n=35$ & 11 & Ref. & & \\
\hline Yes $n=224$ & 40 & 2.95 & 0.53 to 16.35 & 0.215 \\
\hline \multicolumn{5}{|l|}{ General condition } \\
\hline Normal $n=52$ & 21 & Ref. & & \\
\hline III $n=199$ & 40 & 1.52 & 0.57 to 3.98 & 0.399 \\
\hline Severely ill $n=7$ & 71 & 1.30 & 0.14 to 12.02 & 0.817 \\
\hline \multicolumn{5}{|l|}{ Type of doctor } \\
\hline Paediatric emergency clinic $n=108$ & 56 & Ref. & & \\
\hline Out-of-hours services $n=151$ & 9 & 15.65 & 6.06 to 40.43 & $<0.001$ \\
\hline
\end{tabular}

Multiple logistic regression analysis.

${ }^{*}$ Continuous variables.

CRP, C reactive protein; NC, not calculated; Ref., reference. 
Table 4 Distribution of diagnoses, how often CRP is taken on request, CRP values, antibiotic prescription, and referral to hospital for all children

\begin{tabular}{|c|c|c|c|c|c|c|}
\hline Diagnosis & $\begin{array}{l}\text { Patients, } \\
\text { number } \\
n=397\end{array}$ & $\begin{array}{l}\text { CRP on } \\
\text { request, \% } \\
n=259\end{array}$ & $\begin{array}{l}\text { CRP values } \\
\text { (mg/L) in } \\
\text { pretested } \\
\text { group, mean } \\
\mathrm{n}=138\end{array}$ & $\begin{array}{l}\text { CRP values } \\
\text { ( } \mathrm{mg} / \mathrm{L}) \\
\text { in not pretested } \\
\text { group, mean } \\
\mathrm{n}=259\end{array}$ & $\begin{array}{l}\text { Proportion } \\
\text { prescribed } \\
\text { antibiotic, \% } \\
n=397\end{array}$ & $\begin{array}{l}\text { Proportion } \\
\text { referred } \\
\text { to hospital, \% } \\
\mathrm{n}=397\end{array}$ \\
\hline Acute tonsillitis & 47 & 32 & 29 & 45 & 68 & 0 \\
\hline Otitis media & 54 & 40 & 22 & 26 & 67 & 0 \\
\hline Pneumonia & 15 & 80 & 49 & 86 & 67 & 33 \\
\hline URI & 128 & 34 & 15 & 34 & 5 & 2 \\
\hline Viral infection & 31 & 28 & 21 & 16 & 3 & 3 \\
\hline Fever & 20 & 50 & 9 & 54 & 0 & 15 \\
\hline Laryngitis & 17 & 12 & 16 & 19 & 6 & 12 \\
\hline Bronchiolitis & 16 & 10 & 16 & - & 0 & 56 \\
\hline Respiratory infection & 13 & 50 & 27 & 16 & 15 & 0 \\
\hline Cough & 12 & 55 & 7 & 21 & 8 & 8 \\
\hline Asthma & 8 & 17 & 5 & 5 & 12 & 12 \\
\hline Bronchitis & 7 & 50 & 5 & 11 & 42 & 29 \\
\hline Influenza & 5 & 0 & 5 & - & 0 & 20 \\
\hline Gastroenteritis & 5 & 50 & 28 & - & 0 & 40 \\
\hline Pyelonephritis & 2 & 100 & - & 91 & 0 & 100 \\
\hline Other & 17 & 0 & 14 & 11 & 0 & 0 \\
\hline
\end{tabular}

testing in $38 \%$ and that CRP pretesting correlated with increased antibiotic prescription. ${ }^{27}$

The effect of CRP testing on antibiotic prescription has been studied in several settings, with conflicting results. For adult patients, no effect was found for acute bronchitis $^{28}$ or acute pharyngitis. ${ }^{14}$ However, in other studies of respiratory tract infections, CRP testing has resulted in lower prescription rates. ${ }^{15} 16{ }^{29}$ For children, there are fewer studies, but one systematic review from 2011 analysed which CRP values that could be diagnostically useful when trying to rule in or rule out serious infections. ${ }^{10}$ Another study that included clinical signs and CRP in a prediction model found it useful for estimating pneumonia and other serious bacterial infections. ${ }^{30}$ Common for most other studies that look at the effect CRP testing has on antibiotic prescription, is that CRP is used as an intervention in settings where CRP rarely is used. In contrast, we have studied what happens in a low-prevalent population, where CRP is easily accessible, where normal practice and economic incentives stimulate to use CRP very often.

\section{Implications for research and practice}

Antibiotic prescription rates in Norway are relatively low compared with other countries, but still higher than recommended, and many prescriptions do not follow the national guidelines for antibiotic prescription. ${ }^{7}$ The extensive use of CRP in Norway and a tendency towards screening every febrile child with a CRP test, often before the consultation, is not according to any recommendations. There is no evidence for benefit of this practice. Our study shows that CRP screening does not reduce antibiotic prescription rates; the trend is rather an increase. Possibly, prescription rates are increased due to more often false positive CRP values when the test is taken so often at children with low risk of serious infections. Training in communication skills may affect prescription rates, ${ }^{29}$ and should be given priority over extensive laboratory testing in this setting.

Widespread use of antibiotics for otitis media and tonsillitis, such as found in our study, is not recommended according to the national guidelines. The same goes for antibiotic prescriptions for unspecific diagnoses such as cough and upper respiratory infections.

Further studies should focus on how to reduce clinicians' uncertainty with the use of clinical prediction rules validated for low-prevalent populations, and training in communication skills to reduce parents' concern.

\section{CONCLUSION}

CRP is extensively used in children at Norwegian $\mathrm{OOH}$ services, especially when the child has high fever, or if the parents think it is a serious infection. CRP screening of all children with fever and/or respiratory infections will not reduce the prescription of antibiotics.

\section{Author affiliations}

${ }^{1}$ National Centre for Emergency Primary Health Care, Uni Research Health, Bergen, Norway

${ }^{2}$ Department of Global Public Health and Primary Care, University of Bergen, Bergen, Norway

${ }^{3}$ Haukeland University Hospital, Bergen, Norway 
Acknowledgements The authors thank the children, parents, $00 \mathrm{H}$ services at Sotra, Askøy, Nordhordland, Os and the Pediatric Emergency Clinic at Haukeland University Hospital who participated in the study.

Contributors IKR, HS, ABM and SH were involved in the development of the protocol and survey questionnaire. IKR and ABM participated in the data collection. IKR did the analyses and wrote the first draft; all the authors contributed to the interpretation of the data and revision of the manuscript and approved the final version of the manuscript.

Funding The study was funded by Uni Research Health, National Centre for Emergency Primary Health Care and AMFF, The Norwegian Research Fund for General Practice.

Competing interests None declared.

Ethics approval This study was approved by the Regional Committee for Medical and Health Research Ethics (2012/1471/REK Vest).

Provenance and peer review Not commissioned; externally peer reviewed.

Data sharing statement No additional data are available.

Open Access This is an Open Access article distributed in accordance with the Creative Commons Attribution Non Commercial (CC BY-NC 4.0) license, which permits others to distribute, remix, adapt, build upon this work noncommercially, and license their derivative works on different terms, provided the original work is properly cited and the use is non-commercial. See: http:// creativecommons.org/licenses/by-nc/4.0/

\section{REFERENCES}

1. Rebnord IK, Sandvik H, Hunskaar S. Use of laboratory tests in out-of-hours services in Norway. Scand J Prim Health Care 2012;30:76-80.

2. Theodoratou $\mathrm{E}$, Johnson S, Jhass A, et al. The effect of Haemophilus influenzae type $b$ and pneumococcal conjugate vaccines on childhood pneumonia incidence, severe morbidity and mortality. Int J Epidemiol 2010;39(Suppl 1):i172-85.

3. Magnus MC, Vestrheim DF, Nystad W, et al. Decline in early childhood respiratory tract infections in the Norwegian mother and child cohort study after introduction of pneumococcal conjugate vaccination. Pediatr Infect Dis J 2012;31:951-5.

4. NORM/NORM-VET. Usage of antimicrobial agents and occurrence of antimicrobial resistance in Norway. Norwegian surveillance system for antimicrobial resistance (NORM) and Norwegian surveillance system for antimicrobial resistance in veterinary and food production sectors (NORM-VET). Norwegian Veterinary Institute, 2013.

5. Sakshaug S, ed. Drug Consumption in Norway 2009-2013 (Legemiddelforbruket i Norge 2009-2013), Norwegian Institute of Public Health, Oslo, legemiddelstatistikk 2014:1

6. Norwegian Institute of Public Health. http://www.fhi.no/artikler/? $\mathrm{id}=112332$ Published 14.10.2014, updated 07.05.2015, 09:01

7. Linbæk M. Helsedirektoratet, Antibiotikasenteret for primærmedisin. Nasjonale faglige retningslinjer for antibiotikabruk i primærhelsetjenesten Oslo: Helsedirektoratet: Antibiotikasenteret for primærmedisin, 2013.

8. Manzano S, Bailey B, Gervaix A, et al. Markers for bacterial infection in children with fever without source. Arch Dis Child 2011;96:440-6.

9. Rebnord IK, Hunskaar S, Gjesdal S, et al. Point-of-care testing with CRP in primary care: a registry-based observational study from Norway. BMC Fam Pract 2015;16:170.

10. Van den Bruel A, Thompson MJ, Haj-Hassan T, et al. Diagnostic value of laboratory tests in identifying serious infections in febrile children: systematic review. BMJ 2011;342:d3082.
11. Engel MF, Paling FP, Hoepelman Al, et al. Evaluating the evidence for the implementation of C-reactive protein measurement in adult patients with suspected lower respiratory tract infection in primary care: a systematic review. Fam Pract 2012;29:383-93.

12. van der Meer V, Neven AK, van den Broek PJ, et al. Diagnostic value of $C$ reactive protein in infections of the lower respiratory tract: systematic review. BMJ 2005;331:26.

13. Andre M, Eriksson M, Molstad S, et al. The management of infections in children in general practice in Sweden: a repeated 1-week diagnosis-prescribing study in 5 counties in 2000 and 2002. Scand J Infect Dis 2005;37:863-9.

14. Calvino O, Llor C, Gomez F, et al. Association between C-reactive protein rapid test and group A streptococcus infection in acute pharyngitis. J Am Board Fam Med 2014;27:424-6.

15. Andreeva $\mathrm{E}$, Melbye $\mathrm{H}$. Usefulness of $\mathrm{C}$-reactive protein testing in acute cough/respiratory tract infection: an open cluster-randomized clinical trial with $\mathrm{C}$-reactive protein testing in the intervention group. BMC Fam Pract 2014;15:80.

16. Huang $\mathrm{Y}, \mathrm{Chen} \mathrm{R}, \mathrm{Wu} \mathrm{T}$, et al. Association between point-of-care CRP testing and antibiotic prescribing in respiratory tract infections: a systematic review and meta-analysis of primary care studies. $\mathrm{Br} \mathrm{J}$ Gen Pract 2013;63:e787-94.

17. Elshout G, Kool M, Van der Wouden JC, et al. Antibiotic prescription in febrile children: a cohort study during out-of-hours primary care. $J$ Am Board Fam Med 2012;25:810-18.

18. Nordlie AL, Andersen BM. [Changes in antibiotic consumption among day-care children in Oslo]. Tidsskr Nor Laegeforen 2007;127:2924-6.

19. Sandvik $\mathrm{H}$, Hunskår $\mathrm{S}$. [Working style among regular general practitioners and other doctors in the out-of-hours services]. Tidsskr Nor Laegeforen 2010;130:135-8.

20. Hansen EH, Zakariassen E, Hunskaar S. Sentinel monitoring of activity of out-of-hours services in Norway in 2007: an observational study. BMC Health Serv Res 2009:9:123.

21. O'Brien K, Bellis TW, Kelson M, et al. Clinical predictors of antibiotic prescribing for acutely ill children in primary care: an observational study. Br J Gen Pract 2015;65:e585-92.

22. Elshout $\mathrm{G}$, van lerland $\mathrm{Y}$, Bohnen $\mathrm{AM}$, et al. Alarm signs and antibiotic prescription in febrile children in primary care: an observational cohort study. Br J Gen Pract 2013;63:e437-44.

23. Kool M, Monteny M, van Doornum GJ, et al. Respiratory virus infections in febrile children presenting to a general practice out-of-hours service. Eur J Gen Pract 2015;21:5-11.

24. Lass J, Odlind V, Irs A, et al. Antibiotic prescription preferences in paediatric outpatient setting in Estonia and Sweden. Springerplus 2013;2:124.

25. Fossum GH, Lindbaek M, Gjelstad S, et al. Are children carrying the burden of broad-spectrum antibiotics in general practice? Prescription pattern for paediatric outpatients with respiratory tract infections in Norway. BMJ Open 2013;3:pii: e002285.

26. Neumark T, Brudin L, Molstad S. Use of rapid diagnostic tests and choice of antibiotics in respiratory tract infections in primary healthcare-a 6-y follow-up study. Scand J Infect Dis 2010;42:90-6.

27. Lindström J, Nordeman L, Hagström B. What a difference a CRP makes. A prospective observational study on how point-of-care C-reactive protein testing influences antibiotic prescription for respiratory tract infections in Swedish primary health care. Scand $J$ Prim Health Care 2015;33:275-82.

28. Llor C, Plana-Ripoll O, Moragas A, et al. Is C-reactive protein testing useful to predict outcome in patients with acute bronchitis? Fam Pract 2014:31:530-7.

29. Cals JW, Butler CC, Hopstaken RM, et al. Effect of point of care testing for $C$ reactive protein and training in communication skills on antibiotic use in lower respiratory tract infections: cluster randomised trial. BMJ 2009;338:b1374.

30. Nijman RG, Vergouwe $\mathrm{Y}$, Thompson $\mathrm{M}$, et al. Clinical prediction model to aid emergency doctors managing febrile children at risk of serious bacterial infections: diagnostic study. BMJ 2013;346:f1706. 
Correction: Out-of-hours antibiotic prescription after screening with $C$ reactive protein: a randomised controlled study

Rebnord IK, Sandvik H, Batman Mjelle A, et al. Out-of-hours antibiotic prescription after screening with $\mathrm{C}$ reactive protein: a randomised controlled study. BMJ Open 2016;6:e011231. The name segmentation of the third author is incorrect. The author's surname is Mjelle; first name is Anders; middle name is Batman. This author should be cited as 'Mjelle AB'.

Open Access This is an Open Access article distributed in accordance with the Creative Commons Attribution Non Commercial (CC BY-NC 4.0) license, which permits others to distribute, remix, adapt, build upon this work noncommercially, and license their derivative works on different terms, provided the original work is properly cited and the use is non-commercial. See: http://creativecommons.org/licenses/by-nc/4.0/

BMJ Open 2016;6:e011231corr1. doi:10.1136/bmjopen-2016-011231corr1 